\title{
Activation and inhibition of the endogenous opioid system in human heart failure
}

\author{
K G Oldroyd, C E Gray, R Carter, K Harvey, W Borland, G Beastall, S M Cobbe
}

\begin{abstract}
Background-In a canine model of congestive heart failure $\beta$ endorphin concentrations were high and opioid receptor antagonists exerted beneficial haemodynamic effects. In humans previous studies have suggested that opioid peptides may modify the perception of breathlessness and fatigue in heart failure. Methods-Plasma concentrations of $\beta$ endorphin were measured in patients with acute and chronic heart failure and cardiogenic shock. A subgroup of eight patients with New York Heart Association (NYHA) class III-IV heart failure was assessed for acute haemodynamic effects of naloxone, an opioid receptor antagonist. A separate group of 10 patients with class II-III heart failure, was randomised to a double blind placebo controlled study of the effects of intravenous naloxone on cardiopulmonary exercise performance.
\end{abstract}

Results-Plasma concentrations of $\beta$ endorphin were usually normal in patients with chronic heart failure and did not correlate with severity as assessed by NYHA class. In $29 \%$ of patients with acute heart failure and $71 \%$ of those with cardiogenic shock $\beta$ endorphin concentrations were high. The median concentration in the cardiogenic shock group was significantly higher than in either of the two heart failure groups and there was some evidence of a relation between $\beta$ endorphin concentrations and survival. At the doses tested, naloxone was unable to modify systemic haemodynamics, exercise performance, or symptoms in patients with chronic congestive heart failure.

Conclusions-Circulating concentrations of $\beta$ endorphin are usually normal in patients with chronic congestive heart failure. Inhibition of the endogenous opioid system is unlikely to have therapeutic potential in heart failure.

(Br Heart f 1995;73:41-48)

Keywords: heart failure, endogenous opioids.

Endogenous opioid systems are normally quiescent and most cells containing opioid peptides do not release them continuously. Their activation depends upon disruption of homeostasis after the real or perceived imposition of "stress". When opioids are released they generally exert an inhibitory effect on other physiological systems such as pain perception, respiratory and cardiovascular performance, gastrointestinal transit, and certain immunological and behavioural functions. ${ }^{1}$

Plasma concentrations of $\beta$ endorphin, a potent endogenous opioid peptide, are acutely raised in most patients with myocardial infarction. ${ }^{2}{ }^{3}$ They are also increased in a canine model of congestive heart failure, unrelated to any evidence of myocardial ischaemia, and in this model opioid receptor antagonists exert beneficial haemodynamic effects. ${ }^{45}$ In a pattern analagous to their involvement in pain sensation during myocardial ischaemia, ${ }^{67}$ opioid peptides may also modify the perception of breathlessness and fatigue in heart failure. ${ }^{8}$ Thus by a variety of mechanisms endogenous opioid peptides may contribute to the pathophysiology of heart failure.

We postulated that circulating concentrations of $\beta$ endorphin would be raised in human heart failure and that an opioid antagonist would have beneficial effects on systemic haemodynamics, cardiopulmonary exercise performance, and symptoms.

\section{Patients and methods}

All of the study protocols received approval from the Ethics Committee of Glasgow Royal Infirmary.

\section{NEUROENDOCRINE ASSAYS}

The $\beta$ endorphin radioimmunoassay has been independently validated in this institution and the method has been described previously. ${ }^{3}$ The antisera used are unusually specific, with only $1.6 \%$ cross reactivity with synthetic human lipotrophic pituitary hormone $(\beta \mathrm{LPH}$, Peninsula Corporation). The normal range (mean 2 SDs) of this assay in 60 volunteers sampled at 0900 was $2 \cdot 5-7 \cdot 2$ pmol. $^{-1}$. The SD of repeated measurements of $\beta$ endorphin calculated according to the method of Bland and Altman ${ }^{9}$ was 0.5 pmol. $^{-1}$. Adrenocorticotrophic hormone (ACTH) was measured by radioimmunoassay in unextracted plasma according to the method of Nicholson et al. ${ }^{10}$ Cortisol was measured in a direct solid phase radioimmunoassay system. ${ }^{11}$ Arginine vasopressin (AVP) and angiotensin II were measured with standard well described radioimmunoassays.

NALOXONE ASSAY

This was modified from a previously published method with the main improvement 
being in the method of extraction. ${ }^{12}$ Naloxone and the internal standard naltrexone were extracted from serum by solid phase techniques and measured by high performance liquid chromatography with electrochemical detection. The lower limit of detection was 10 nmol. $1^{-1}$ with a mean recovery of $95 \%$ from $1 \mathrm{ml}$ samples of serum spiked with $500 \mathrm{pmol}$ of naloxone. The following drugs were shown not to interfere: dihydrocodeine to $4.5 \mu \mathrm{mol}^{-1}{ }^{-1}$, codeine to $\mu \mathrm{mol} .1^{-1}$, salicylate, to 1.5 mmol. $1^{-1}$, paracetamol to $1.0 \mathrm{mmol}^{-1} \mathrm{l}^{-1}$, propranolol, metoprolol, diltiazem, nifedipine, and captopril. Precision was $5.0 \%$ at 200 nmol. $1^{-1}$ and $4 \cdot 8 \%$ at $900 \mathrm{nmol.1} 1^{-1}$.

\section{ASSESSMENT OF LEFT VENTRICULAR EJECTION FRACTION}

This was performed with cross sectional echocardiography and all scans were acquired and analysed by one experienced observer (KGO) with an ATL Ultramark 8 system. Simpson's formula was used to calculate left ventricular volumes. ${ }^{13}$ In our hands, the SD of repeated measurements of left ventricular ejection fraction by this technique is $3.35 \%$ with a normal result being $>55 \%$. $^{14}$

$\beta$ ENDORPHIN CONCENTRATIONS IN PATIENTS WITH HEART FAILURE OR CARDIOGENIC SHOCK Opioid peptide concentrations were measured on a single occasion in three groups of patients with heart failure or cardiogenic shock. Patients with stable congestive heart failure were recruited from out patient clinics. Patients with acute or acute to chronic congestive heart failure or cardiogenic shock were identified from emergency admissions to the coronary or intensive care units. Other than this, patients were unselected and recruited consecutively.

Heart failure was defined on clinical criteria and evidence of ventricular dysfunction on echocardiography or radionuclide ventriculography. Cardiogenic shock was defined by the criteria of Cohn. ${ }^{15}$ Patients with heart failure or cardiogenic shock but recent myocardial infarction ( $<48$ hours) or ongoing chest pain were excluded. We have previously shown that in patients with acute myocardial infarction, the high $\beta$ endorphin concentrations seen on admission have in all cases returned to normal within this period. ${ }^{3}$

\section{ACUTE HAEMODYNAMIC EFFECTS OF NALOXONE IN CONGESTIVE HEART FAIIURE Patients}

Patients with stable chronic congestive heart failure were eligible for this study. All cardioactive drug treatment, other than sublingual glyceryl trinitrate, was withdrawn for at least 36 hours. Patients were admitted to hospital one day before the planned study and a Swan-Ganz triple lumen thermodilution catheter was placed in the pulmonary artery percutaneously through the femoral or internal jugular vein. Patients were confined to bed overnight and for the duration of the study the next morning. Only a light breakfast of tea and toast was allowed.

\section{HAEMODYNAMIC MEASUREMENTS}

Heart rate was recorded continuously and blood pressure was measured non-invasively by a semiautomatic electronic cuff sphygmomanometer (Hewlett Packard). Right atrial, pulmonary artery, and pulmonary capillary wedge pressures were recorded with electronically calibrated transducers and a seven channel ink jet chart recorder (Siemens Mingograf 7). The pressure recordings were all digitised on line to provide mean and phasic values that were immediately entered into a microcomputer (Epson HX-20) linked to an American Edwards cardiac output computer.

Protocol

Naloxone administration schedules were designed from previously published pharmacokinetic data ${ }^{16}$ and aimed to achieve plasma concentrations in the range $1-100$ nmol.1 $1^{-1}$. At these concentrations in vitro, antagonism at all opioid receptor subtypes can be expected. ${ }^{1819}$ Naloxone was given intravenously by incremental infusion starting at $1.0 \mu \mathrm{g} \cdot \mathrm{kg}^{-1} \mathrm{~min}^{-1}$ with an approximate doubling of the dose every 20-30 minutes up to $20.0 \mu \mathrm{g} \cdot \mathrm{kg}^{-1} \mathrm{~min}^{-1}$. Bolus doses were given before each increase in the infusion to accelerate a steady state in plasma concentrations. Haemodynamic data were acquired twice 30 minutes apart at baseline and the results were averaged. Thereafter measurements were made immediately before each increase in dose and 45-60 minutes after the end of the naloxone infusion. Plasma samples were taken at baseline, before each increase in naloxone and 45-60 minutes after the end of the infusion for the measurement of $\beta$ endorphin, ACTH, cortisol, and naloxone.

ACUTE EFFECTS OF NALOXONE ON EXERCISE PERFORMANCE AND SYMPTOMS IN PATIENTS WITH CONGESTIVE HEART FAIIURE

Patients

Patients for this study were selected from outpatient clinics. Inclusion criteria were impaired left ventricular function secondary to ischaemic heart disease or dilated cardiomyopathy and a reduced exercise tolerance limited by dyspnoea or fatigue but not angina or exercise induced myocardial ischaemia. Patients who had valvar heart disease, evidence of significant pulmonary disease on resting pulmonary function tests $\left(\mathrm{FEV}_{1} / \mathrm{FVC}\right.$ $<40 \%$ ), or who could not consistently reproduce their maximal oxygen consumption during the practice exercise tests were excluded. All patients gave fully informed written consent before entry into the study.

\section{Exercise tests}

Maximal symptom limited cardiopulmonary treadmill exercise tests with 12 lead electrocardiographic monitoring were performed with the standardised exponential exercise protocol (STEEP). ${ }^{20}$ This protocol produces exponential rather than linear increases in workload in one minute increments. The small frequent increases minimise problems of patient boredom and the learning effect, while 
facilitating the detection of an anaerobic threshold. Respiratory gas exchange was measured with a closed loop breathing circuit. The inspired limb of the circuit was fitted with a turbine ventilometer and the expired limb connected to a mixing chamber from which expiratory gases were measured with polarographic oxygen and infrared carbon dioxide analysers. The output of the ventilometer and gas analysers were processed by an on line microcomputer to allow continuous measurement of respiratory gas exchange and inspired minute ventilation (PK Morgan Exercise Test System).

\section{Symptoms}

Visual analogue scales for dyspnoea and fatigue were displayed on the monitor of a BBC microcomputer as horizontal uncalibrated bars, annotated with the words "none" at one end and "severe" at the other. With a linear potentiometer mounted on the treadmill and inputting directly to the microcomputer, patients were able to indicate their estimation of the severity of the relevant symptom during exercise by moving the position of a cursor from extreme left (equivalent to a score of 0 ) to extreme right (a score of 100). The modified Borg scale was also used at peak exercise. As a measure of dyspnoea, both visual analogue scales and the Borg score correlate well with measured ventilation, the relation being predominantly linear. ${ }^{21}$

\section{Protocol}

At least two practice tests and all of the exercise tests were performed between 0900 and 1200. Immediately before each of the three study exercise tests and after the patients were breathing through the closed respiratory loop of the gas analysing system, each patient received in a double blind randomised order, either placebo or naloxone $\left(0.1 \mathrm{mg} . \mathrm{kg}^{-1}\right.$ or $1.0 \mathrm{mg} \cdot \mathrm{kg}^{-1}$ ) given as a slow bolus intravenous injection over one minute. End points in this study were breathlessness and fatigue assessed as already described and the following measures of cardiovascular and respiratory performance: exercise time, maximal $\mathrm{O}_{2}$ consumption $\left(\mathrm{VO}_{2} \mathrm{max}\right)$ and $\mathrm{CO}_{2}$ production $\left(\mathrm{VCO}_{2}\right)$, transcutaneous $\mathrm{O}_{2}$ and $\mathrm{CO}_{2}$ saturation, $\mathrm{O}_{2}$ consumption at the anaerobic threshold, ventilation (VE), respiratory dead space, and tidal volume. Symptoms were assessed twice during exercise; firstly when the patient had reached $60 \%$ of his previously found $\mathrm{VO}_{2} \mathrm{max}$ and secondly at peak exercise. Peripheral venous blood samples were drawn from an indwelling cannula before and after

Table 1 Circulating concentrations (median (interquartile range)) of $\beta$ endorphin, $A C T H$, and cortisol in patients with congestive heart failure (CHF) and cardiogenic shock

\begin{tabular}{lllllll}
\hline & No $\begin{array}{l}\beta \text { endorphin } \\
\left(p m o l . l^{-1}\right)\end{array}$ & No & ACTH $\left(\right.$ nmol.l $\left.l^{-1}\right)$ & No & Cortisol $\left(\right.$ nmol. $\left.l^{-1}\right)$ \\
\hline Chronic CHF & 34 & $4 \cdot 4(3 \cdot 7-5 \cdot 4)$ & 34 & $1 \cdot 0(1 \cdot 0-3 \cdot 3)$ & 31 & $323^{\star}(255-500)$ \\
Acute CHF & 28 & $5 \cdot 2^{\star \star}(3 \cdot 8-7 \cdot 8)$ & 28 & $1.0(1 \cdot 0-3 \cdot 6)$ & 27 & $690^{\star \star}(500-898)$ \\
Cardiogenic shock & 14 & $9 \cdot 8^{\star \star}(6 \cdot 8-25 \cdot 0)$ & 14 & $3 \cdot 9^{\star \star}(1 \cdot 0-19 \cdot 0)$ & 12 & $1302^{\star \star}(1127-2540)$ \\
\hline${ }^{\star} \mathrm{P}<0.001 v$ acute CHF; ${ }^{\star \star} \mathrm{P}<0 \cdot 01 v$ chronic CHF.
\end{tabular}

exercise and assayed for naloxone, $\beta$ endorphin, ACTH, and cortisol.

\section{DATA ANALYSIS}

In the observational study, $\beta$ endorphin, ACTH, and cortisol results were skewed and so are reported as median (interquartile range) with groups being compared by MannWhitney $U$ tests. Rank correlation coefficients were calculated by Spearman's method. Open label naloxone was given in the haemodynamic studies but the data were digitised and analysed on line by microcomputer. This removed, to some extent, the problems of within-observer variability and bias. Accordingly, further analysis by an independent observer was not performed. Haemodynamic and exercise variables were normally distributed and are reported as mean(SD) or mean(SEM). Group comparisons were made by repeated measures or one way analysis of variance followed by modified $t$ tests if appropriate.

\section{Results}

$\beta$ ENDORPHIN CONCENTRATIONS IN PATIENTS WITH HEART FAILURE OR CARDIOGENIC SHOCK The number of patients with concentrations $>$ the upper limit of normal was three of 34 (9\%) with chronic heart failure, eight of 28 $(29 \%)$ with acute heart failure, and 10 of 14 (71\%) with cardiogenic shock (fig 1 and table 1). Median values in the heart failure groups were not significantly different from each other. Two of the three patients with chronic heart failure and high concentrations were in NYHA class III $(\beta$ endorphin 8.2 and $10 \cdot 2$ pmol.1 $\left.1^{-1}\right)$ and the other was in class IV $(\beta$ endorphin 13.3 pmol.1 $1^{-1}$ ). Patients with cardiogenic shock had significantly higher concentrations than either of the two heart failure groups. The four patients with cardiogenic

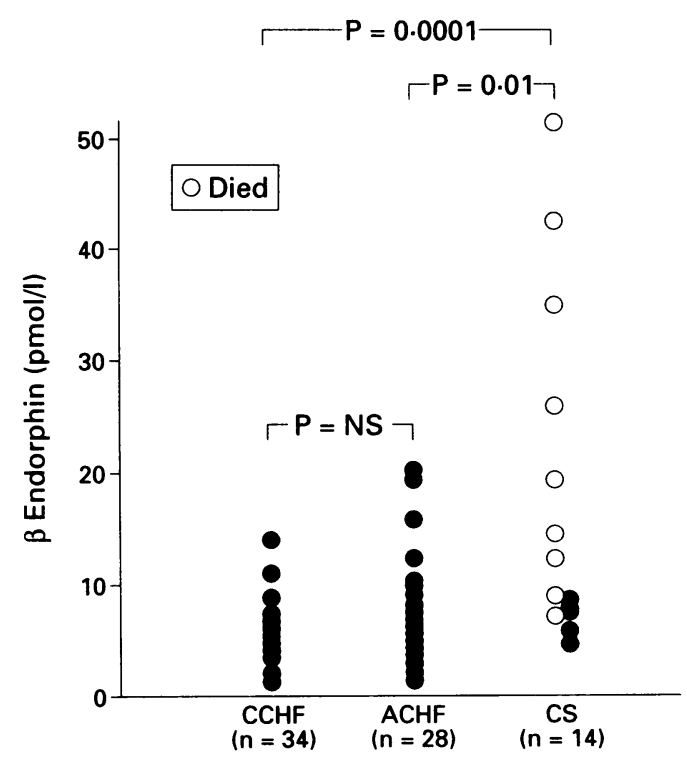

Figure 1 Individual $\beta$ endorphin concentrations in consecutive patients with chronic (CCHF) or acute (ACHF) congestive heart failure or cardiogenic shock (CS). 
Table 2 Clinical details of the patients with chronic congestive heart failure studied to assess the acute effects of naloxone on haemodynamics, symptoms and exercise capacity

\begin{tabular}{|c|c|c|c|c|c|c|}
\hline Age & $\operatorname{Sex}$ & NYHA & Diagnosis & LVEF (\%) & $\begin{array}{l}\text { Frusemide } \\
\left(\text { mg.day }^{-1}\right)\end{array}$ & $F E V_{1} / F V C(\%)$ \\
\hline $\begin{array}{l}70 \\
50 \\
56 \\
48 \\
49 \\
60 \\
56 \\
24\end{array}$ & $\begin{array}{l}\mathbf{F} \\
\mathbf{M} \\
\mathbf{M} \\
\mathbf{M} \\
\mathbf{M} \\
\mathbf{M} \\
\mathbf{M} \\
\mathbf{M}\end{array}$ & $\begin{array}{l}\text { III-IV } \\
\text { III } \\
\text { IV } \\
\text { III } \\
\text { IV } \\
\text { III } \\
\text { III } \\
\text { III-IV }\end{array}$ & $\begin{array}{l}\text { aemodynamic } \\
\text { DCM } \\
\text { IHD } \\
\text { IHD } \\
\text { IHD } \\
\text { IHD } \\
\text { IHD } \\
\text { IHD } \\
\text { DCM }\end{array}$ & $\begin{array}{l}u d y(n=8) \\
18 \\
15 \\
15 \\
17 \\
20 \\
21 \\
25 \\
19\end{array}$ & $\begin{array}{r}160 \\
160 \\
80 \\
80 \\
250 \\
120 \\
240 \\
80\end{array}$ & $\begin{array}{l}- \\
z \\
- \\
- \\
-\end{array}$ \\
\hline \multicolumn{7}{|c|}{$\begin{array}{lc}\text { Exercise study }(n=10) \\
\text { IHD } & 22 \\
\text { IHD } & 29 \\
\text { IHD } & 25 \\
\text { IHD } & 10 \\
\text { IHD } & 28 \\
\text { IHD } & 18 \\
\text { IHD } & 20 \\
\text { IHD } & 16 \\
\text { DCM } & 10 \\
\text { IHD } & 11\end{array}$} \\
\hline
\end{tabular}

LVEF, left ventricular ejection fraction; $F E V_{1} / F V C$, forced expiratory volume in 1 forced vital capacity; IHD, ischaemic heart disease; DCM, dilated cardiomyopathy.

shock and normal $\beta$ endorphin concentrations all survived their initial stay in hospital, as did one other patient with cardiogenic shock whose $\beta$ endorphin concentration on admission was marginally high at $7 \cdot 8$ pmol. $1^{-1} . \beta$ Endorphin concentrations were high in eight of nine patients with cardiogenic shock who did not survive to discharge. The median (interquartile range) concentration in the survivors was $6.8(4 \cdot 9-7 \cdot 2) \mathrm{pmol}^{-1} \quad v \quad 18.7$ $(11 \cdot 5-34 \cdot 1)$ pmol.1 $1^{-1}$ in the non-survivors, $P=0.01$. Of all 76 patients, $\beta$ endorphin concentrations were significantly lower in the 63 patients who survived their stay in hospital than the 13 who did not (4.9 (3.7-6.7) pmol.1 $1^{-1}$ o $13.6 \quad(6 \cdot 4-25 \cdot 0)$ pmol.1 ${ }^{-1} \quad \mathrm{P}=$ $0.001)$.

Relation between $\beta$ endorphin concentrations and other neuroendocrine and clinical variables

Table 1 shows that median ACTH concentrations were similar in the two heart failure groups but patients with cardiogenic shock had a significantly higher ACTH concentration than those with chronic heart failure. There was a significant positive correlation between $\beta$ endorphin concentrations and ACTH $\quad(r=0.58, \quad \mathrm{P}=0.00001, \quad \mathrm{n}=76)$.
Median cortisol concentrations in each of the three groups were significantly different from each other. There was a weak positive correlation between cortisol and $\beta$ endorphin concentrations $(r=0.36, \mathrm{P}=0.003, \mathrm{n}=70)$.

Within all patients, univariate rank correlation analysis showed no significant relation between $\beta$ endorphin concentrations and any of the following: age, aetiology of heart failure, heart rate, systolic and diastolic blood pressure, jugular venous pressure, simultaneously measured concentrations of creatinine or angiotensin II, left ventricular ejection fraction, and the daily dose of frusemide. There was a weak but significant correlation between $\beta$ endorphin and arginine vasopressin $(r=$ $0.46, P=0.005, n=38) . \beta$ endorphin concentrations were not different in patients with and without cardiomegaly or pulmonary oedema.

Considering only the patients with chronic heart failure, there were no significant correlations between $\beta$ endorphin concentration and either New York Heart Association (NYHA) class or the use of angiotensin converting enzyme (ACE) inhibitors. In six patients $\beta$ endorphin was measured before and one week after the start of treatment with captopril. The plasma concentration increased in five of six patients and was unchanged in the sixth; median (interquartile range) concentration before treatment was $4.0(3.6-5.0) \mathrm{pmol}^{-1}$ $v 4 \cdot 4(3 \cdot 7-5 \cdot 8) \mathrm{pmol}^{-1}$ one week later, $\mathrm{P}=0 \cdot 10$.

\section{ACUTE HAEMODYNAMIC EFFECTS OF} NALOXONE IN PATIENTS WITH CHRONIC CONGESTIVE HEART FAILURE

Table 2 shows the clinical characteristics of the eight patients included in this study. Their mean age was 52 (range 24-70) and all were in NYHA class III-IV. In six of eight patients the aetiology of their heart failure was ischaemic heart disease, the other two patients had dilated cardiomyopathy. The mean left ventricular ejection fraction was $19 \%$ (range $15-25 \%$ ) and the mean daily dose of frusemide was 145 (range 80-250) $\mathrm{mg}^{-d_{a y}{ }^{-1}}$. No adverse effects were reported during the naloxone infusion by any of the patients. Naloxone had no significant effects on any of the variables measured (table 3 ).

Table 3 Effects of an incremental intravenous infusion of naloxone on a range of haemodynamic variables in eight patients with chronic congestive heart failure

\begin{tabular}{|c|c|c|c|c|c|c|c|c|}
\hline & \multirow[b]{2}{*}{ Control } & \multicolumn{7}{|c|}{ Naloxone $\left(\mu \mathrm{g} \cdot \mathrm{kg}^{-1} \cdot \mathrm{min}^{-1}\right)$} \\
\hline & & $1 \cdot 0$ & $2 \cdot 5$ & $5 \cdot 0$ & $10 \cdot 0$ & $20 \cdot 0$ & After & $P$ value \\
\hline 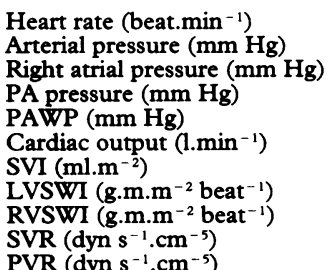 & $\begin{array}{c}94(7) \\
94(4) \\
4(1) \\
31(3) \\
22(3) \\
5 \cdot 2(0 \cdot 5) \\
31(4) \\
29(4) \\
13(2) \\
1396(164) \\
133(19)\end{array}$ & $\begin{array}{c}92(7) \\
93(4) \\
5(2) \\
29(4) \\
22(3) \\
4 \cdot 9(0 \cdot 5) \\
30(4) \\
28(4) \\
12(2) \\
1472(168) \\
121(28)\end{array}$ & $\begin{array}{l}92(7) \\
93(3) \\
6(2) \\
30(3) \\
23(2) \\
4 \cdot 9(0 \cdot 5) \\
30(4) \\
28(4) \\
12(2) \\
1479(176) \\
129(34)\end{array}$ & $\begin{array}{l}91(6) \\
97(5) \\
6(2) \\
29(3) \\
23(2) \\
4 \cdot 8(0 \cdot 5) \\
29(3) \\
29(4) \\
12(2) \\
1568(175) \\
117(23)\end{array}$ & $\begin{array}{c}86(9) \\
89(2) \\
7(2) \\
33(4) \\
24(3) \\
4 \cdot 8(0 \cdot 6) \\
29(4) \\
26(5) \\
13(1) \\
1448(133) \\
168(43)\end{array}$ & $\begin{array}{c}87(11) \\
92(4) \\
3(1) \\
32(6) \\
20(3) \\
5 \cdot 1(0 \cdot 7) \\
31(4) \\
31(6) \\
13(2) \\
1491(204) \\
212(78)\end{array}$ & $\begin{aligned} 96(9) \\
101(6) \\
4(1) \\
31(4) \\
22(4) \\
4 \cdot 9(0 \cdot 6) \\
29(4) \\
29(3) \\
12(3) \\
1624(262) \\
165(54)\end{aligned}$ & $\begin{array}{l}\text { NS } \\
\text { NS } \\
\text { NS } \\
\text { NS } \\
\text { NS } \\
\text { NS } \\
\text { NS } \\
\text { NS } \\
\text { NS } \\
\text { NS } \\
\text { NS }\end{array}$ \\
\hline
\end{tabular}

PA, pulmonary artery; PAWP, pulmonary artery wedge pressure; SVI, stroke volume index; LVSWI, left ventricular stroke work index; RVSWI, right ventricular stroke work index; SVR, systemic vascular resistance; PVR, pulmonary vascular resistance. Values are mean (SD). 
Table 4 Effect of an incremental intravenous infusion of naloxone on the median interquartile range concentrations of $\beta$ endorphin, $A C T H$, and cortisol in eight patients with congestive heart failure

\begin{tabular}{|c|c|c|c|}
\hline & Baseline & After-naloxone & $P$ value \\
\hline $\begin{array}{l}\beta \text { Endorphin } \\
\text { (pmol.1-1) } \\
\text { ACTH } \\
(\text { pmol.1-1) } \\
\text { Cortisol } \\
(\text { nmol.1-1) }\end{array}$ & $\begin{array}{l}4 \cdot 2 \\
(3 \cdot 8-5 \cdot 3) \\
1 \cdot 0 \\
(1 \cdot 0-1 \cdot 0) \\
328 \\
(270-486)\end{array}$ & $\begin{array}{l}5 \cdot 8 \\
(3 \cdot 4-8 \cdot 4) \\
1 \cdot 0 \\
(1 \cdot 0-3 \cdot 4) \\
404 \\
(336-650)\end{array}$ & $\begin{array}{l}0.44 \\
0.37 \\
0.10\end{array}$ \\
\hline
\end{tabular}

\section{Plasma naloxone concentrations}

The intravenous protocol used in these patients produced concentrations of $>1 \mu \mathrm{mol} .1^{-1}$ in seven of eight patients with the eighth patient only reaching a peak concentration of $0.2 \mu \mathrm{mol}^{-1} \mathrm{1}^{-1}$. The mean(SD) peak concentration in all eight patients was 11.0 (14.5) $\mu \mathrm{mol} .1^{-1}$.

\section{Neuroendocrine measurements}

At baseline, one patient had a slightly raised $\beta$ endorphin concentration $\left(8 \cdot 2\right.$ pmol. $\left.1^{-1}\right)$ but all of the other seven patients had normal concentrations. In two of these seven patients concentrations increased to above the upper limit of normal after intravenous naloxone. Overall, concentrations of $\beta$ endorphin, ACTH, and cortisol tended to be higher after naloxone, but none of the differences from baseline reached significance (table 4).

\section{Correlations between $\beta$ endorphin concentrations} and haemodynamic indices

Invasive haemodynamic data were available for a total of 22 patients including 14 from the observational study. Spearman rank correlation coefficients did not suggest any significant relations between $\beta$ endorphin concentration and heart rate, arterial pressure (phasic or mean), right atrial pressure, pulmonary artery pressure, pulmonary capillary wedge pressure, cardiac index, stroke volume index, left or right ventricular stroke work index, and systemic or pulmonary vascular resistance.

Table 5 Effects of the double blind administration of placebo and low and high doses of naloxone on cardiorespiratory function during symptoms limited treadmill exercise in 10 patients with stable congestive heart failure

\begin{tabular}{|c|c|c|c|c|}
\hline & Placebo & $\begin{array}{l}\text { Noloxone } \\
\left(0.1 \mathrm{mg}^{\left.-\mathrm{kg}^{-1}\right)}\right.\end{array}$ & $\begin{array}{l}\text { Noloxone } \\
\left(1.0 \mathrm{mg}^{\left.-\mathrm{kg}^{-1}\right)}\right.\end{array}$ & $\begin{array}{l}\text { ANOVA } \\
P \text { value }\end{array}$ \\
\hline 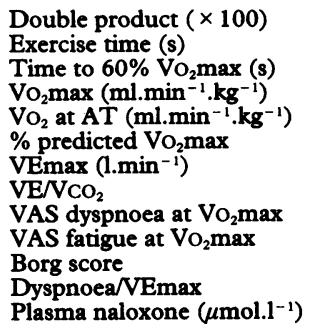 & $\begin{array}{l}180(40) \\
538(147) \\
274(90) \\
17 \cdot 7(3 \cdot 8) \\
12 \cdot 1(1 \cdot 7) \\
56 \cdot 9(9 \cdot 6) \\
56 \cdot 6(15 \cdot 3) \\
40 \cdot 1(12 \cdot 8) \\
64(12) \\
61(13) \\
4 \cdot 3(1 \cdot 3) \\
1 \cdot 25(0 \cdot 57) \\
-\end{array}$ & $\begin{array}{l}182(40) \\
555(197) \\
309(134) \\
17 \cdot 6(4 \cdot 6) \\
11 \cdot 6(1 \cdot 6) \\
57 \cdot 4(15 \cdot 6) \\
56 \cdot 1(15 \cdot 8) \\
38 \cdot 5(12 \cdot 0) \\
71(10) \\
62(12) \\
4 \cdot 7(1 \cdot 3) \\
1 \cdot 35(0 \cdot 34) \\
0 \cdot 31(0 \cdot 48)\end{array}$ & $\begin{array}{l}173(41) \\
533(169) \\
283(111) \\
17 \cdot 0(3 \cdot 4) \\
12 \cdot 0(1 \cdot 6) \\
55 \cdot 0(11 \cdot 0) \\
57 \cdot 3(15 \cdot 2) \\
40 \cdot 1(10 \cdot 0) \\
65(16) \\
67(9) \\
4 \cdot 1(1 \cdot 2) \\
1 \cdot 21(0 \cdot 42) \\
8 \cdot 05(7 \cdot 08)\end{array}$ & $\begin{array}{l}0.24 \\
0.78 \\
0.63 \\
0.66 \\
0.46 \\
0.67 \\
0.80 \\
0.74 \\
0.25 \\
0.19 \\
0.33 \\
0.62 \\
0.0009\end{array}$ \\
\hline
\end{tabular}

$\mathrm{VO}_{2}$ max, maximal oxygen consumption; $\mathrm{AT}$, anaerobic threshold; VEmax, maximal ventilation $\mathrm{VCO}_{2}$, carbon dioxide production; VAS, visual analogue scores (maximum $=100$ ). Values are mean (SD).
EFFECTS OF NALOXONE ON EXERCISE CAPACITY AND SYMPTOMS IN HEART FAILURE

A total of 22 screening exercise tests were performed to identify 10 suitable subjects (table 2). The 10 patients were all men, aged from $30-65$, and all were in NYHA functional class II-III with left ventricular ejection fractions ranging from $10-29 \%$. In one case, the aetiology of the heart failure was idiopathic dilated cardiomyopathy and in the others it was ischaemic heart disease. The mean daily dose of frusemide was $92 \mathrm{mg}$ and all of the patients except one were receiving treatment with ACE inhibitors.

\section{Cardiopulmonary exercise variables}

All 10 patients successfully completed each of their three study exercise tests. Table 5 shows the results. Neither dose of naloxone had any significant effect on the basal values of $\mathrm{O}_{2}$ consumption or ventilation. Total exercise duration and the time to reach $60 \%$ of previously achieved $\mathrm{Vo}_{2} \max$ were similar in all three groups. Thus a similar workload was performed at each exercise test. The $\mathrm{Vo}_{2} \max$ and the $\mathrm{VO}_{2}$ at the anaerobic threshold were virtually identical providing no evidence of either an increased exercise capacity or an improved exercise efficiency with naloxone (figure 2). Maximal ventilation was similar in
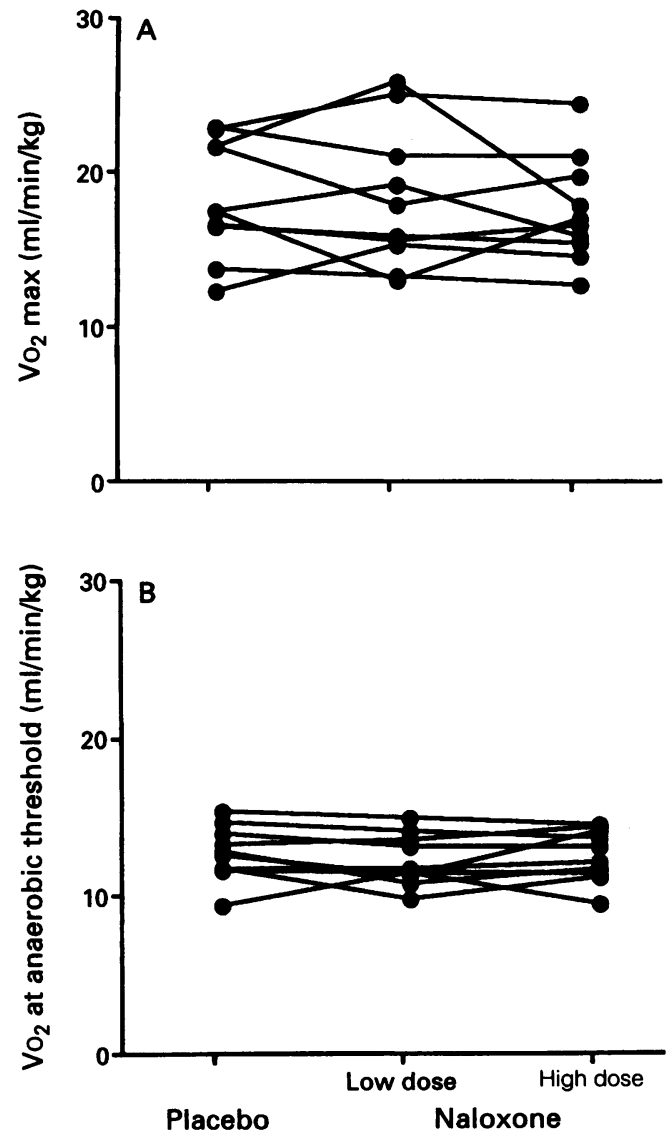

Figure 2 Effect of naloxone on maximal $(A)$ oxygen consumption (Vo max) and (B) $\mathrm{O}_{2}$ consumption at the anaerobic threshold in 10 patients with chronic congestive heart failure who performed symptom limited heart failure who performed symp
cardiopulmonary exercise tests. 
all three groups, as was the ventilatory response to $\mathrm{CO}_{2}$ production $\left(\mathrm{VE} / \mathrm{VCO}_{2}\right)$.

\section{Symptoms}

Dyspnoea at both submaximal and maximal workloads was similar in all three groups. The ratio of the visual analogue score to ventilation at maximal workload was also not different between the groups. Visual analogue scores for fatigue were almost as high as those for dyspnoea and were not influenced by naloxone either at submaximal or maximal workloads.

\section{Neuroendocrine variables}

Before exercise, concentrations of $\beta$ endorphin were similar at each of the three exercise tests $(F=0.02, \quad \mathrm{P}>0.80)$. Within each group, concentrations after exercise were significantly higher after naloxone but not after placebo. Naloxone enhanced the exercise induced increase in $\beta$ endorphin concentrations in a dose dependent manner $(F=4.35$, $P=0.03$ ). Measurements of ACTH and cortisol were only available for eight patients. In 20 of 48 samples assayed, ACTH concentrations were below the lower limit of detection of the assay $\left(2 \mathrm{pmol} .1^{-1}\right)$. In these patients an arbitrary value of 1 pmol.1 $1^{-1}$ was inserted and the subsequent statistical comparisons were made with non-parametric techniques. The ACTH and cortisol concentrations were increased by exercise but none of the within group differences reached significance.

\section{Plasma naloxone concentrations}

After the lower dose of naloxone, mean plasma concentrations ranged from $0.05-1.56$ $\mu$ mol. $^{-1}$ after exercise. The 10 -fold higher dose increased plasma concentrations by an average of 26-fold with all patients exceeding $1 \mu \mathrm{mol} .1^{-1}$ and two exceeding $10 \mu \mathrm{mol}^{-1}$ : range $1 \cdot 04-22 \cdot 10 \mu \mathrm{mol}^{-1}{ }^{-1}$. There were weak correlations between the plasma concentration of naloxone at the end of exercise and both the $\beta$ endorphin concentration after exercise $(r=0.48, \mathrm{P}=0.04)$ and the percentage change in $\beta$ endorphin concentrations induced by exercise $(r=0.43, \mathrm{P}=0.07)$.

Correlations between $\beta$ endorphin concentrations and exercise performance

Simple linear regression analysis showed no significant correlations between $\beta$ endorphin concentrations before or after exercise and any variable of cardiopulmonary exercise performance. This finding was consistent whether each of the three treatment groups were examined separately or together. There was also no correlation with visual analogue scores for fatigue, but in the placebo group, scores for dyspnoea correlation with concentrations after exercise $(r=-0 \cdot 70, P=0 \cdot 04)$. This relation was lost when the patients exercised after being given either a low dose $(r=0.44, \mathrm{P}=0.23)$ or high dose $(r=0.43$, $\mathrm{P}=0 \cdot 25)$ of naloxone.

\section{Discussion}

$\beta$ ENDORPHIN CONCENTRATIONS IN PATIENTS WITH HEART FAILURE

Kawashima et al reported a good correlation between NYHA class and $\beta$ endorphin concentration in 37 patients with chronic congestive heart failure. ${ }^{22}$ In a similar group of patients with heart failure we found high $\beta$ endorphin concentrations in only three patients and could not show any relationship with NYHA class. A larger proportion of our patients with acute heart failure and most of those with cardiogenic shock had high $\beta$ endorphin concentrations. The significant differences between $\beta$ endorphin concentrations in those patients surviving their stay in hospital both in the whole group and particularly in those with cardiogenic shock are intriguing. There may be some relation between the magnitude of a haemodynamic disturbance and the stimulus to opioid peptide release.

OPIOID PEPTIDES AND ACE INHIBITORS

The exercise induced euphoria reported by endurance athletes has been attributed to enhanced release of endogenous opioid peptides. ${ }^{23}{ }^{24}$ This has also been offered as an explanation for the uplifting effect on mood of ACE inhibitors. ${ }^{25} 26$ In normal subjects, captopril did not increase concentrations of leu-enkephalin and met-enkephalin either before or after exercise, but it did enhance the exercise induced rise in the plasma concentration of $\beta$ endorphin. In our patients with chronic heart failure, $\beta$ endorphin concentrations were not higher in those taking an ACE inhibitor. In the six patients in whom concentrations were measured before and one week after the start of ACE inhibitor treatment, there was a trend towards higher concentrations.

Table 6 Effect of placebo and naloxone at low $\left(0.1 \mathrm{mg} \cdot \mathrm{kg}^{-1}\right)$ and high $\left(1.0 \mathrm{mg} \cdot \mathrm{kg}^{-1}\right)$ dose on plasma concentrations of $\beta$ endorphin $(n=9)$, adrenocorticotrophin $(n=8, A C T H)$, and cortisol $(n=8)$ before and after exercise in patients with stable chronic congestive heart failure

\begin{tabular}{|c|c|c|c|c|c|c|c|c|c|}
\hline & \multicolumn{3}{|l|}{ Placebo } & \multicolumn{3}{|c|}{ Naloxone $\left(0.1 \mathrm{mg}^{\left.-\mathrm{kg}^{-1}\right)}\right.$} & \multicolumn{3}{|c|}{ Naloxone $\left(1.0 \mathrm{mg} \cdot \mathrm{kg}^{-1}\right)$} \\
\hline & Before & After & $\begin{array}{l}\text { Percentage } \\
\text { change }\end{array}$ & Before & After & $\begin{array}{l}\text { Percentage } \\
\text { change }\end{array}$ & Before & After & $\begin{array}{l}\text { Percentage } \\
\text { change }\end{array}$ \\
\hline $\begin{array}{l}\beta \text { Endorphin } \\
\left(\text { pmol. } 1^{-1}\right) \\
\text { ACTH }\end{array}$ & $6 \cdot 3(2 \cdot 7)$ & $8 \cdot 6(5 \cdot 8)$ & $29(43)$ & $6 \cdot 2(2 \cdot 8)$ & $11 \cdot 3^{\star}(4 \cdot 0)$ & $87(43)$ & $6 \cdot 1(2 \cdot 9)$ & $12 \cdot 8^{\star}(7 \cdot 8)$ & $121^{\star \star}(96)$ \\
\hline$\left(\right.$ pmol.1 $\left.1^{-1}\right)$ & $1(1-9 \cdot 4)$ & $2 \cdot 4(1-12 \cdot 6)$ & $2(0-34)$ & $1 \cdot 5(1-7 \cdot 4)$ & $8 \cdot 8(3-17 \cdot 9)$ & $206(6-385)$ & $1(1-4 \cdot 8)$ & $9 \cdot 8(6-28 \cdot 4)$ & $538(224-880)$ \\
\hline $\begin{array}{l}\text { Cortisol } \\
\quad\left(\text { nmol. }^{-1}\right)\end{array}$ & $380(151)$ & $396(196)$ & $2(19)$ & $353(134)$ & $415(156)$ & $21(22)$ & $323(154)$ & $349(69)$ & $23(42)$ \\
\hline
\end{tabular}

${ }^{\star} \mathrm{P}<0.05 v$ before exercise; ${ }^{\star \star} \mathrm{P}<0.05 v$ placebo. Values are mean (SD) except for ACTH, which are median interquartile range. 
HAEMODYNAMIC EFFECTS OF NALOXONE IN HEART FAILURE

In the canine model of chronic congestive heart failure studied by Liang et al, the intravenous dosage the opioid antagonist nalmafene resulted in significant increases in mean arterial pressure, cardiac output, left ventricular $\mathrm{dP} / \mathrm{dt}$, and regional blood flow to the myocardium, skeletal muscle (quadriceps), and kidney. $\beta$ Adrenoceptor blockade abolished the effects on cardiac output and ventricular contractility whereas $\alpha$ adrenoceptor blockade prevented the pressor response. This clearly suggests that the beneficial effects were mediated through the sympathetic nervous system. Further studies indicated that the effects were produced centrally and were not related to any change in pain sensation. ${ }^{45}$

The failure of our study and a similar previous study ${ }^{27}$ to reproduce these haemodynamic effects in patients with severe congestive heart failure may be due to several differences between clinical heart failure in humans and that in the particular animal model used by Liang et al. ${ }^{4}$ Berger et al first described the use of tricuspid valve avulsion and progressive pulmonary artery occlusion to produce stable heart failure in dogs. ${ }^{28}$ Although predominantly right sided failure develops, many of the haemodynamic, neuroendocrine, and biochemical features of clinical congestive cardiac failure including evidence of left ventricular dysfunction are also seen. ${ }^{29}$ Our patients had serious left ventricular dysfunction, however, and, as Liang's group suggested, the effects of naloxone on myocardial contractility may differ in the left and right ventricles. The naloxone dose used in our clinical studies was substantially higher than that shown to be effective in Liang's canine model. In fact plasma concentrations were achieved that in vitro have been associated with a non-receptor mediated enhancement of myocardial contractility. ${ }^{3031}$

EXERCISE, OPIOID PEPTIDES, AND SYMPTOMS IN HEART FAILURE

Circulating $\beta$ endorphin concentrations rise acutely after strenuous physical exercise in normal people. ${ }^{32}$ There is a threshold of exercise intensity for producing this effect and training augments the increase. ${ }^{33}$ Acute physical exercise in our patients with congestive heart failure also increased the circulating concentration of $\beta$ endorphin and had a similar effect on ACTH and cortisol. Comparison with the normal volunteer studies cited earlier does not suggest that the exercise induced rise in these circulating hormones is either enhanced or attenuated in patients with stable chronic heart failure. These increases were enhanced, in a dose dependent manner, by the prior treatment with naloxone. In percentage terms, the largest rise after naloxone was in ACTH, although the reasons for this are not clear. It is not possible to determine whether there is an exercise threshold required to provoke a rise in plasma $\beta$ endorphin in heart failure as there is in normal people, nor whether the degree of enhance- ment by naloxone reflects the underlying concentration of activation within the endogenous opioid system. In our patients, there was no relation between exercise intensity and $\beta$ endorphin concentrations before or after exercise, but in 16 patients with dilated cardiomyopathy, Kawashima's group found that $\beta$ endorphin concentrations before exercise were inversely correlated with exercise capacity. ${ }^{22}$

Modulation of opioid receptors may alter the perception of breathlessness in patients with heart failure. Davies et al found that naloxone, given intravenously immediately before exercise, increased the sensation of dyspnoea at a standard workload and slightly reduced $\mathrm{Vo}_{2} \max$. By contrast, dihydrocodeine, an opioid receptor agonist, reduced dyspnoea and increased $\mathrm{Vo}_{2} \mathrm{max}$. In a finding analogous to that described previously in patients with angina, objective measures of pain sensation correlated with indices of dyspnoea. ${ }^{34}$ The opposite results obtained with the antagonist and agonist in these patients suggested that these effects were receptor mediated. Opioids modify the respiratory response to hypercapnia, but no data on $\mathrm{CO}_{2}$ production or ventilation were provided. In a second study morphine was given through a nebuliser to patients with heart failure. In this case, the opioid agonist did not reduce either the sensation of dyspnoea or maximal ventilation. Despite this, slight but significant improvements in exercise duration and $\mathrm{Vo}_{2} \max$ were again found. ${ }^{35}$ In our patients with heart failure, intravenous naloxone had no effect on either symptom perception or exercise capacity. Our patients were similar in age and severity of heart failure to those studied by Kawashima et $a l^{22}$ and Davies et al, ${ }^{34}$ thus any difference in study population seems unlikely to account for the differing results.

\section{WHAT DO HIGH CIRCULATING}

CONCENTRATIONS OF OPIOID PEPTIDES MEAN?

Many studies have confirmed that it is difficult to define the level of activity within the sympathetic nervous system and particularly the cardiac adrenergic nerves by monitoring circulating concentrations of adrenaline, the main hormonal component of the system. Similarly it is not known whether there is any correlation between circulating $\beta$ endorphin concentrations and the level of inhibitory input from prejunctional opioid receptors within areas of the autonomic and central nervous systems involved in cardiovascular regulation. If there is, then clearly the essentially normal concentrations found in our patients with chronic heart failure would not suggest a significant degree of activation. In patients with cardiogenic shock, who do have high $\beta$ endorphin concentrations, further studies on the effects of naloxone would be of interest.

IF OPIOID PEPTIDES ARE BAD FOR YOU, WHY DO WE STILL HAVE THEM?

Teleologically, it has been postulated that endorphins are critical to the coping mechanisms and survival of the organism. In a quiescent state when blood pressure is normal, 
opioids are not released and giving an opioid antagonist has, as in our patients, no detectable effect. After a stress such as major haemorrhage, endorphins are released and contribute to analgesia and hypotension. Hypotension may be a highly protective mechanism by reducing the driving pressure in the bleeding vessels and assisting coagulation. Under certain conditions, however, particularly septic shock, endogenous opioid peptide release may be less helpful and opioid receptor antagonists can produce dramatic improvements in blood pressure. ${ }^{36}{ }^{37}$ In response to other, evolutionary younger stresses, such as acute myocardial infarction, release of opioid peptide may be similarly inappropriate.

KGO was a British Heart Foundation Junior Research Fellow. This study was also supported by the Greater Glasgow Health Board Endowments Fund.

1 Imura H, Kato Y, Nakai Y, et al. Endogenous opioids and related peptides: from molecular biology to clinical and related peptides: from molecular bio

2 Bach FW, Fahrenkrug J, Jensen K, Dahlstrøm G, Ekman R. Plasma $\beta$-endorphin during clinical and experimental R. Plasma $\beta$-endorphin during clinical and experimental ischaemic pain. Scand $\mathcal{F}$ Clin Lab Invest 1987;47:751-8.
Oldroyd KG, Harvey K, Gray CE, Beastall GH, Cobbe Oldroyd KG, Harvey K, Gray CE, Beastall GH, Cobbe
SM. $\beta$-Endorphin release in man after spontaneous and SM. $\beta$-Endorphin release in man after spontaneous and
provoked myocardial ischaemia. $\mathrm{Br}$ Heart $\mathcal{f} 1992 ; 67$ : $230-5$.

4 Liang C-s, Imai N, Stone CK, Woolf PD, Kawashima S, Tuttle $R$. The role of endogenous opioids in congestive heart failure; effects of nalmafene on systemic and regional hemodynamics in dogs. Circulation 1987;75: 443-51.

5 Sukamoto S, Stone CK, Woolf PD, Liang C-s. Opiate receptor antagonism in right-sided congestive heart failure. Circ Res 1989;65:103-114.

6 Droste C, Roskamm H. Pain measurement and pain modification by naloxone in patients with asymptomatic myocardial ischemia. In: Rutishauer W, Roskamm H, eds. Silent myocardial ischaemia. Berlin: Springer-Verlag, 1984;14-23.

7 Sheps DS, Adams KF, Hinderliter A, et al. Endorphins are related to pain perception in coronary artery disease. $\mathrm{Am}$ related to pain perception

8 Davies SW, Jordan SL, Lipkin DP. Central modulation of dyspnoea in chronic heart failure related to opioid axis [abstract]. Br Heart $\mathcal{F} 1990 ; 64: 58-9$.

9 Bland JM, Altman DG. Statistical methods for assessing agreement between two methods of clinical measurement. Lancet 1986;i:307-10.

10 Nicholson WE, Davis DR, Sherrell BJ, Orth DN. Rapid radioimmunoassay for corticotrophin in unextracted human plasma. Clin Chem 1984;30:259-65.

11 McConway MG, Chapman R. Development and validation of a simple direct solid phase radioimmunoassay of serum cortisol from readily available agents. Clin Chim Acta 1986;158:59-70.

12 Albeck H, Woodfield S, Kreek MJ. Quantitative and pharmacokinetic analysis of naloxone in plasma using HPLC with electrochemical detection and solid phase with electrochemical detection and $₹$ Chromatogr 1989;488:435-45.

13 Starling MR Crawford MH, Sorensen SG, Levi B, Richards KL, O'Rourke RA. Comparative accuracy of apical biplane cross-sectional echocardiography and apical biplane cross-sectional echocardiography and gated equilibrium radionuclide angiography for estimat1981;63:1075-83.
14 Oldroyd KG, Pye M, Ray SG, Christie J, Ford I, Cobbe SM, Dargie HJ. Effects of early captopril administration on infarct expansion, ventricular remodelling and exercise capacity after acute myocardial infarction. $\mathrm{Am} F$ Cardiol 1991;68:713-8.

15 Cohn J. Recognition and management of shock and acute pump failure. In: Hurst JW, ed. The heart. 5th ed. New York: McGraw-Hill, 1982:463-76.

16 Aitkenhead AR, Derbyshire DR, Pinnock CA, Achola K, Smith G. Parmacokinetics of intravenous naloxone in healthy volunteers. Anesthesiology 1984;61:A381.

17 Vozeh S, Schmidlin O, Taescher W. Pharmacokinetic drug data. Clin Pharmacokinet 1988;15:254-82.

18 Lord JAH, Waterfield AA, Hughes J, Kosterlitz HW. Endogenous opioid peptides: multiple agonists and Endogenous opioid peptides: m
receptors. Nature 1977;267:495-9.

19 Paterson SJ, Robson LE, Kosterlitz HW. Classification of opioid receptors. Br Med Bull 1983;39:31-6.

20 Northridge DB, Grant S, Ford I, et al. Novel exercise protocol suitable for use on a treadmill or a bicycle ergometer. Br Heart f 1990;64:313-6.

21 Wilson RC, Jones PW. A comparison of the visua analogue scale and modified Borg scale for the measurement of dyspnoea during exercise. Clin Sci 1989;76: 277-82.

22 Kawashima S, Fukutake N, Nishian K, Asakuma S, Iwasaki $T$. Elevated plasma beta-endorphin levels in patients with congestive heart failure. $7 \mathrm{Am}$ Coll Cardiol 1991;17:53-8.

23 Carr DB, Bullen BA, Skrinar GS, et al. Physical conditioning facilitates the exercise-induced secretion of beta-endorphin and beta-lipotropin in women. $N$ Engl $f$ Med 1981;305:560-3.

24 Rahkila $P$, Hakala $E$, Alén $M$, Laatikainen $K S$, $\beta$-endorphin and corticotrophin release is dependent on a phin and corticotrophin release is dependent on a threshold intensity of running exercise

25 Croog SH, Levine S, Testa MA, et al. The effects of antihypertensive therapy on quality of life. $N$ Engl $f \mathrm{Med}$ hypertensive therapy

26 Zubenko GS, Nixon RA. Mood-elevating effect of captopril in depressed patients. Am $\mathcal{F}$ Psychiatry 1984 141:110-1

27 Kindman LA, Fowler MB. Hemodynamic effects of high dose naloxone in congestive heart failure. $A m \mathcal{F}$ Cardio 1989;64:542-3.

28 Berger AC, Roe BB, Richardson GS. Relation of valvula lesions and of exercise to auricular pressure, work tolerance and development of chronic congestive failure in dogs. Am $\mathcal{F}$ Physiol 1952;169:384-99.

29 Fan T-HM, Liang C-s, Kawashima S, Baneriee SP. Alterations in cardiac $\beta$-adrenoceptor responsiveness and adenylate cyclase system by congestive heart failure in dogs. Eur $¥$ Pharmacol 1987; 140:123-32.

30 Sagy M, Shavit DG, Oran Y, Vidne BA, Gitter S, Sarne Y. Nonopiate effect of naloxone on cardiac muscle contracNonopiate effect of naloxone on cardiac mu

31 oldroyd KG, Hicks $\mathrm{MN}$, Cobbe SM. Influence of hyperkalaemia and ischaemia on non-receptor-mediated hyperkalaemia and ischaemia on non-receptor-mediated cardiac electrophysiological effec

32 Carr DB, Bullen BA, Skrinar GS, et al. Physical conditioning facilitates the exercise-induced secretion of betaendorphin and beta-lipotropin in women. $N$ Engl $f \mathrm{Med}$ 1981;305:560-3.

33 Farrell PA, Gates WK, Maksud MG, Morgan WP Increases in plasma $\beta$-endorphin $/ \beta$-lipotropin immunoreactivity after treadmill running in humans. $f A p p$ Physiol 1982;52:1245-9.

34 Davies SW, Jordan SL, Lipkin DP. Central modulation of dyspnoea in chronic heart failure related to opioid axis [abstract]. Br Heart f 1990;64:58-9.

35 Uren NG, Davies SW, Jordan SL, Lipkin DP. Increased exercise capacity after nebulised diamorphine in chronic heart failure [abstract]. Br Heart $\mathcal{f}$ 1991;66:112.

36 Vargish T, Beamer K. Hemodynamic effects of naloxone in early canine hypovolemic shock. Circ Shock 1985;17: 45-7.

37 Gurll NJ, Reynolds DG, Holaday JW. Evidence for a role of endorphins in the cardiovascular pathophysiology of endorphins in the cardiovascular pathophysio
primate shock. Crit Care Med 1988;16:521-30. 